\title{
The soluble amino-terminal region of HVEM mediates efficient herpes simplex virus type 1 infection of $\mathrm{gD}$ receptor-negative cells
}

\author{
Hyunjung Baek ${ }^{1,2}$, Jae Hong Kim², Yoon Tae Noh ${ }^{1}$ and Heechung Kwon ${ }^{1 *}$
}

\begin{abstract}
Background: Previous studies from our own and other labs reported the surprising finding that the soluble $\mathrm{V}$ domain of the herpes simplex virus type 1 (HSV-1) entry receptor nectin-1 can both block HSV infection of receptor-bearing cells and mediate infection of receptor-deficient cells. Here we show that this property is not unique to nectin-1. We generated a pair of truncated, soluble forms of the other major HSV-1 entry receptor, herpes virus entry mediator (HVEM or HveA), and examined its effects on HSV-1 infection of receptor-deficient cells.

Results: In cultures of $\mathrm{CHO}-\mathrm{K} 1$ cells, $\mathrm{sHve}_{102}$ comprising the two amino-terminal cysteine-rich pseudorepeats (CRPs) of HVEM enabled infection of greater than $80 \%$ of the cells at an $\mathrm{MOI}$ of 3, while sHve $\mathrm{A}_{162}$ comprising the complete ectodomain failed to mediate infection. Both sHveA 102 and $\mathrm{sHveA}_{162}$ blocked infection of $\mathrm{CHO}-\mathrm{K} 1$ cells stably expressing HVEM in a dose-dependent manner, indicating that both were capable of binding to viral gD. We found that $\mathrm{sHveA}_{102}$-mediated infection involves $\mathrm{pH}$-independent endocytosis whereas HSV infection of HVEMexpressing $\mathrm{CHO}-\mathrm{K} 1$ cells is known to be $\mathrm{pH}$-dependent.
\end{abstract}

Conclusions: Our results suggest that the C-terminal portion of the soluble HVEM ectodomain inhibits gD activation and that this effect is neutralized in the full-length form of HVEM in normal infection.

Keywords: HSV-1, HVEM/HveA, gD, Soluble entry receptor

\section{Background}

Herpes simplex virus type 1 (HSV-1) infects a broad range of mammalian cells, including epithelial cells, lymphocytes, and post-mitotic neurons. Initial HSV attachment to host cells is mediated by the binding of viral envelope glycoproteins $C(\mathrm{gC})$ and $\mathrm{gB}$ to ubiquitous heparan sulfate moieties on the surface of cells [1-3]. While not essential [4], these interactions facilitate the binding of glycoprotein $\mathrm{D}(\mathrm{gD})$ to one or more of its cognate cell-surface receptors, nectin-1 (HveC), HVEM (HveA), and 3-O-sulfated heparan sulfate (3-OS HS) [5-7]. Binding to these entry receptors causes conformational changes in the gD ectodomain that signal activation of the downstream effectors of HSV entry, gB and $\mathrm{gH} / \mathrm{gL}$, the proximal mediators of membrane fusion and

\footnotetext{
* Correspondence: hck@kcch.re.kr

'Division of Radiation Oncology, Korea Institute of Radiological and Medical Sciences, 215-4, Gongneung-Dong, Nowon-Ku, Seoul 139-706, South Korea Full list of author information is available at the end of the article
}

capsid delivery into the cytoplasm [8-12]. Recent studies have also demonstrated that PILR $\alpha$ (paired immunoglobulin-like type-2 receptor) and non-muscle myosin heavy chain IIA can function as HSV-1 entry co-receptors through interaction with $\mathrm{gB}[13,14]$.

The absolute dependence of HSV-1 infection on gD binding to a cognate receptor indicates that the tropism of the virus is determined at least in part by the distribution of gD receptors. Nectin- 1 is a member of the immunoglobulin superfamily and is expressed on many cell types, including fibroblasts, epithelial cells and neurons [15]. Nectins function as intercellular adhesion molecules localized to cadherin-based adherens junctions [16]. The variable $(\mathrm{V})$ domain of nectin-1 is sufficient for binding to $\mathrm{gD}$ and the initiation of fusion between the virus envelope and cell membranes [17]. HVEM is a member of the tumor necrosis factor receptor (TNFR) superfamily and is expressed in hematopoietic cells and lymphoid tissues such as spleen and thymus [18,19]. HVEM contains 
four cysteine-rich pseudorepeats (CRPs) characteristic of members of the TNFR family in its ectodomain and functions as a mediator of HSV-1 and HSV-2 entry mainly into human lymphocytes $[6,19]$. The natural ligands for HVEM include LIGHT, lymphotoxin alpha (Lt- $\alpha$ ), Band T-lymphocyte attenuator (BTLA), and CD160 [20]. The contribution of the third gD receptor, 3-OS HS, to the broad HSV-1 tropism is not as clearly defined since this glycosaminoglycan modification is not easily detectable by immunological or other methods. However, novel approaches are beginning to reveal the role of this receptor [21].

X-ray crystallography has shown that HVEM binds to a flexible hairpin at the amino terminus of gD [8]. A variety of mutations in this region, including Q27P originally identified in KOS-rid1 virus [22], abolish HVEM binding $[23,24]$. Using a series of truncated forms of HVEM, Whitbeck and colleagues demonstrated that the two N-terminal CRPs of HVEM are required and sufficient for binding to HSV-1 gD [25]. In their study, HveA(120 t), consisting of the first and second CRP, showed full gD binding activity by competition ELISA and blocked HSV entry into $\mathrm{CHO}$ cells expressing HVEM.

We previously reported that the V-domain of nectin-1 as a soluble form can mediate efficient virus entry into HSV-resistant CHO-K1 cells that lack gD receptors [26]. Here, we have investigated whether soluble forms of the HVEM ectodomain have a similar ability. To this end, we constructed soluble recombinant proteins consisting of the first two CRPs $\left(\mathrm{sHA}_{102}\right)$ or the full ectodomain $\left(\mathrm{sHA}_{162}\right)$ of HVEM. While both soluble proteins inhibited HSV infection of HVEM-expressing CHO-K1 cells, only $\mathrm{sHA}_{102}$ mediated virus entry into receptor-negative $\mathrm{CHO}$ $\mathrm{K} 1$ cells. Infection mediated by $\mathrm{sHA}_{102}$ was highly efficient, involved specific binding of $\mathrm{sHA}_{102}$ to viral gD, required heparin-sensitive virus attachment to the cells, and took place by a $\mathrm{pH}$-independent endocytic mechanism as opposed to the $\mathrm{pH}$-dependent mechanism mediating HSV infection of HVEM-expressing CHO cells [27]. Our results indicate that the C-terminal portion of the HVEM ectodomain contains sequences that inhibit gD activation and suggest a context effect allowing gD activation by fulllength HVEM, but not the soluble ectodomain, in the acidic milieu of endosomes.

\section{Results}

\section{Production of soluble gD receptors}

We constructed expression plasmids for two $\mathrm{His}_{6}$-tagged soluble HVEM proteins, $\mathrm{sHA}_{102}$ containing the gD-binding first two CRPs (102 aa), and $\mathrm{sHA}_{162}$ comprising the full ectodomain (162 aa) (Figure 1A). Soluble proteins were produced by transfection of $293 \mathrm{~T}$ cells and purified from the culture supernatant, as previously described [26]. The molecular size $\mathrm{sHA}_{102}$ was approximately $15 \mathrm{kDa}$
(Figure 1B, C), somewhat larger than the predicted size of $11 \mathrm{kDa}$ most likely due to N-linked glycosylation in CRP2 [28]. sHA $_{162}$ migrated predominantly as a $38 \mathrm{kDa}$ species, significantly larger than the predicted $18 \mathrm{kDa}$ for the monomeric form, suggesting incomplete denaturation of the dimeric form that predominates in solution [28].

\section{Soluble HVEM-mediated HSV-1 infection of CHO-K1 cells}

We determined whether $\mathrm{sHA}_{102}$ and $\mathrm{sHA}_{162}$ could mediate HSV-1 entry into $\mathrm{CHO}-\mathrm{K} 1$ cells that are resistant to infection due to the absence of entry receptors. KOS/tk12, expressing LacZ from the viral thymidine kinase (tk) locus in a wild-type (strain KOS) viral background [29], was preincubated at a multiplicity of $3 \mathrm{pfu} /$ cell with $\mathrm{CHO}-\mathrm{K} 1$ cells in suspension for $1 \mathrm{~h}$ at $4^{\circ} \mathrm{C}$. Increasing concentrations (0$1,000 \mathrm{nM}$ ) of sHA proteins were then added and the cells were incubated for $1 \mathrm{~h}$ at $37^{\circ} \mathrm{C}$, plated, and incubated for another $7 \mathrm{~h}$ at $37^{\circ} \mathrm{C}$ prior to measurement of $\beta$-galactosidase activity by quantitative ONPG assay. As shown in Figure 2A, dose-dependent infection was observed in the presence of $\mathrm{sHA}_{102}$, whereas $\mathrm{sHA}_{162}$ failed to mediate infection. At an MOI of 9, infection reached a plateau at $500 \mathrm{nM} \mathrm{sHA}_{102}$ (Figure 2B), suggesting that either the amount of virus or the number of cells became limiting at this concentration. A similar level of infection was observed at an MOI of 3 with 1,000 nM sHA $\mathrm{n}_{102}$, arguing for the second interpretation. Indeed, titration of $\mathrm{X}$-gal stained cells showed infection of $90-100 \%$ of the cells at an MOI of 9 at 500-1,000 nM sHA 102 (Figure 2C). These results demonstrated that the known gD binding region of HVEM consisting of CRPs 1 and 2 was sufficient to mediate HSV entry into receptor-deficient cells. As shown in Figure 2D, the efficiency of $\mathrm{sHA}_{102}$-mediated entry was comparable to that mediated by the soluble $\mathrm{V}$ domain of nectin-1 $\left(\mathrm{sNec}_{123}\right)$ described previously [26].

\section{Soluble HVEM blocks HSV infection of HVEM-expressing CHO cells}

Soluble forms of HVEM and nectin-1 have been shown to inhibit HSV-1 entry through the cognate cellular receptors by competition for gD binding [28]. To determine whether the distinct entry-mediating activities of our $\mathrm{sHA}_{102}$ and $\mathrm{sHA}_{162}$ preparations correlated with their ability to inhibit virus entry via HVEM, we carried out competitive inhibition assays on $\mathrm{CHO}$ cells expressing HVEM. Cells were infected with KOS/tk12 in the presence of soluble gD receptors and $\beta$-galactosidase expression was measured by ONPG assay. As shown in Figure 4, expression decreased with increasing amounts of $\mathrm{sHA}_{102}$ and $\mathrm{sHA}_{162}$, indicating dose-dependent entry inhibition. While 1,000 $\mathrm{nM}$ of $\mathrm{sHA}_{102}$ was required to inhibit KOS/tk12 infection by approximately $50 \%$, $\mathrm{sHA}_{162}$ reached this level of inhibition at $250 \mathrm{nM}$. The greater blocking efficiency of $\mathrm{sHA}_{162}$ is in sharp contrast to its lack of entry-mediating activity on 


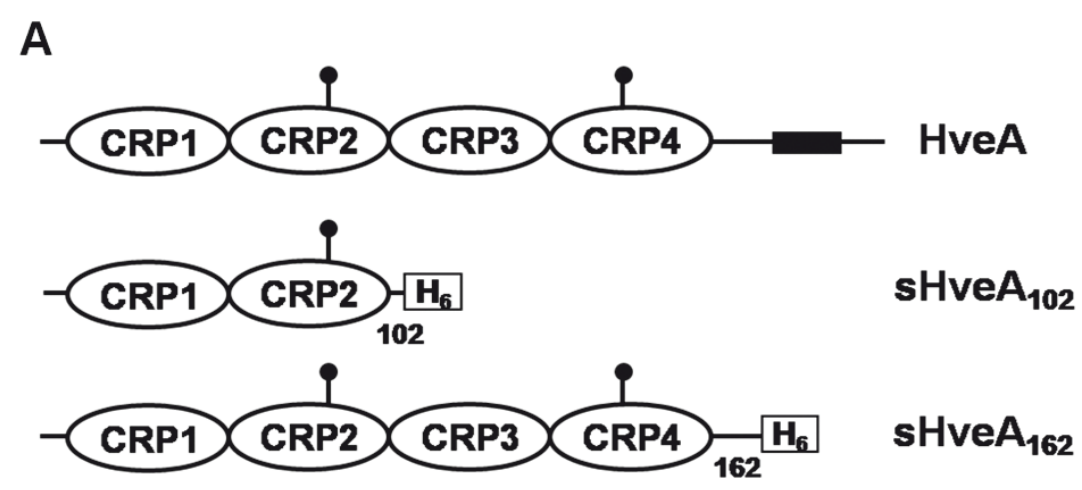

B
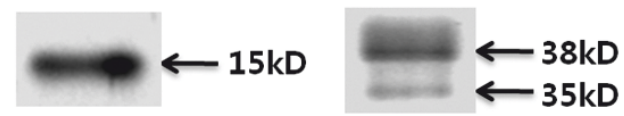

sHveA $_{102}$

sHveA $_{162}$

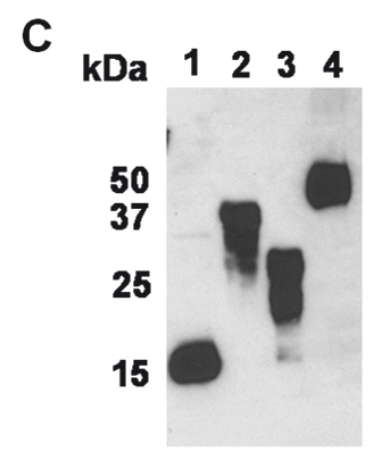

Figure 1 Structure and expression of soluble HVEM proteins. (A) Schematic representations of full-length HVEM (HveA) and the truncated HVEM proteins produced for this study. Lollipops indicate glycosylation sites and numbers indicate amino acid positions relative to position 1 of mature HVEM. CRP, cysteine-rich pseudorepeat; $\mathrm{H}_{6}$, six-histidine tag. (B) Silver-stained SDS-PAGE gels of soluble protein samples. (C) Western blot detection of purified recombinant soluble proteins using anti-His tag antibody. Lane 1, sHA $\mathrm{A}_{102}$; lane 2, sHA $\mathrm{A}_{162}$; lane 3, sNec1 123 used in Figure 2D; lane $4, \mathrm{sgD}_{287}$ used in Figure 3.

receptor-deficient cells. One possible explanation is that CRP 3 and 4, when not anchored in the cell membrane, sterically limit the activation of gD involving partial unfolding to expose its effector/pro-fusion domain $[10,12]$.

\section{Specific interaction of $\mathrm{sHA}_{102}$ with viral $\mathrm{gD}$}

We determined whether $\mathrm{sHA}_{102}$-mediated virus entry into $\mathrm{CHO}-\mathrm{K} 1$ cells requires specific interaction with gD. As illustrated in Figure 3, while $\mathrm{sHA}_{102}$ promoted entry of $\mathrm{KOS} /$ tk12 into CHO-K1 cells, little entry was observed by an isogenic mutant virus, KOS-Rid1/tk, that has an amino-acid substitution in gD preventing interaction with HVEM [29]. In addition, we observed that preincubation of $\mathrm{sHA}_{102}$ with soluble gD ectodomain ( $\mathrm{gD}_{287}$; Figure. $1 \mathrm{C}$ ) inhibited virus entry into $\mathrm{CHO}-\mathrm{K} 1$ cells in a $\mathrm{sgD}_{287}$ dosedependent manner. When the concentration of $\mathrm{sHA}_{102}$ was augmented up to $100 \mathrm{nM}$, the viral infection was recovered to 2 fold (Figure 3 ). Together, these results indicated that $\mathrm{sHA}_{102}$-mediated $\mathrm{HSV}$ entry into $\mathrm{CHO}-\mathrm{K} 1$ cells occurred through specific binding to viral gD.

\section{Requirement of heparan sulfate binding for $\mathrm{sHA}_{102^{-}}$} mediated infection

HSV attachment is mediated by the binding of $\mathrm{gB}$ and gC to cell-surface glycosaminoglycans, particularly heparan sulfate [30]. To determine whether heparan sulfate binding was required for $\mathrm{sHA}_{102}$-mediated $\mathrm{HSV}$ entry, infections were performed in the presence of 25 $\mu \mathrm{g} / \mathrm{ml}$ heparin. As shown in Figure 5, infection was reduced at all MOIs tested, including more than 200fold at an MOI of 10 . These results indicated that virus attachment to cell-surface heparan sulfate is necessary for efficient $\mathrm{sHA}_{102}$-mediated HSV entry, as previously observed for soluble nectin-1-mediated infection [26]. 


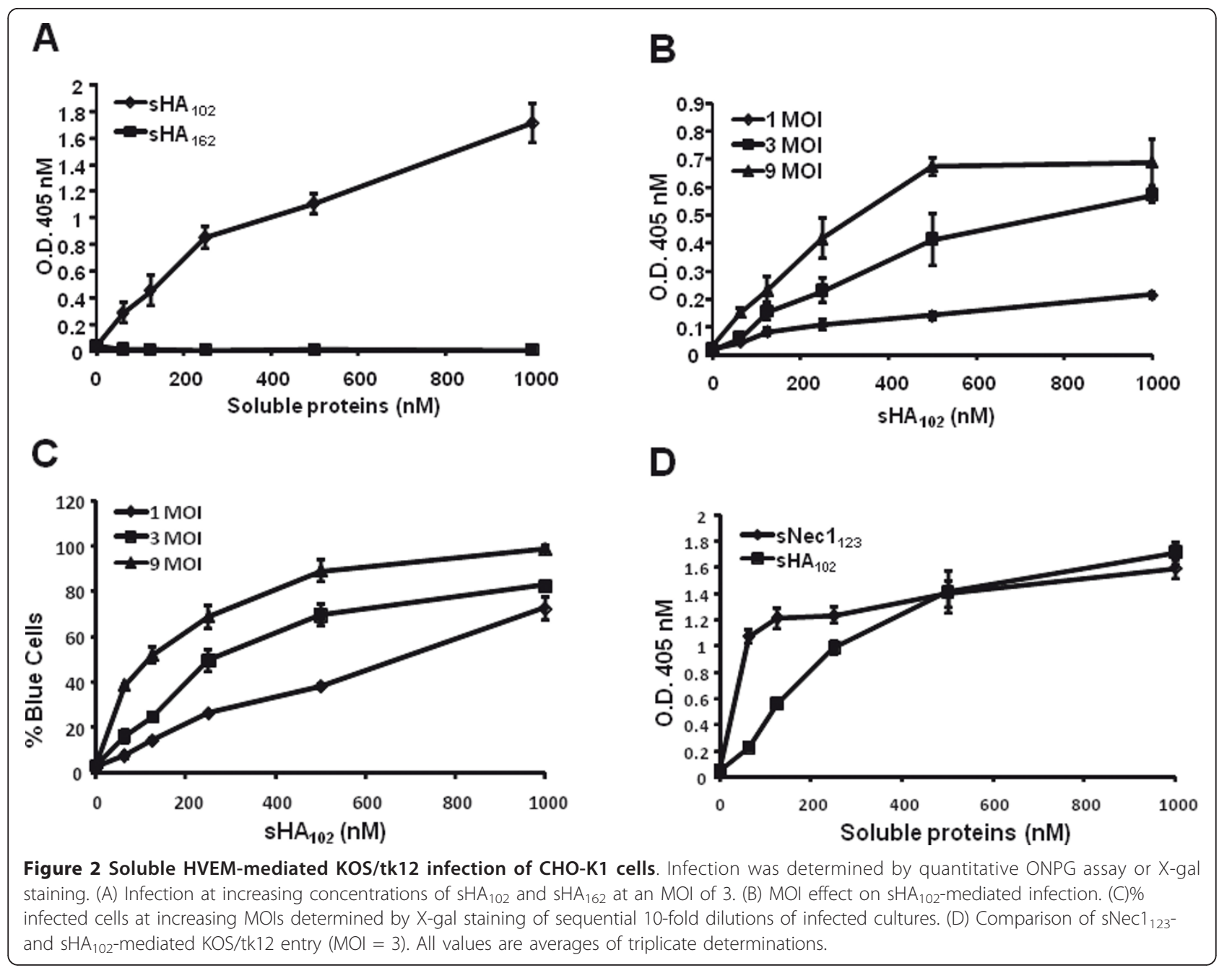

A

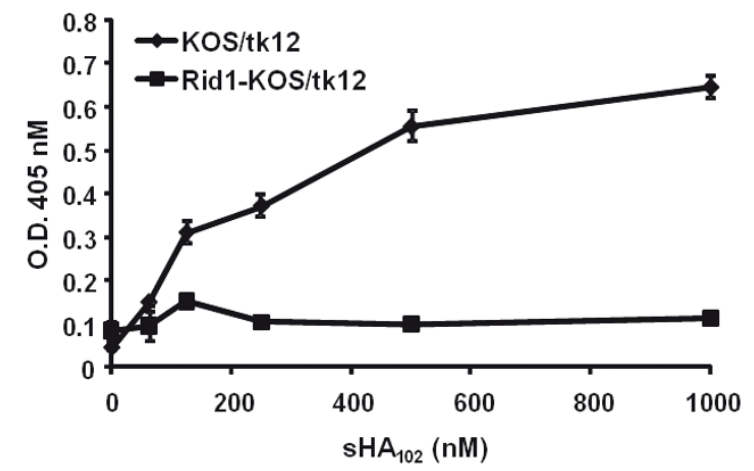

B

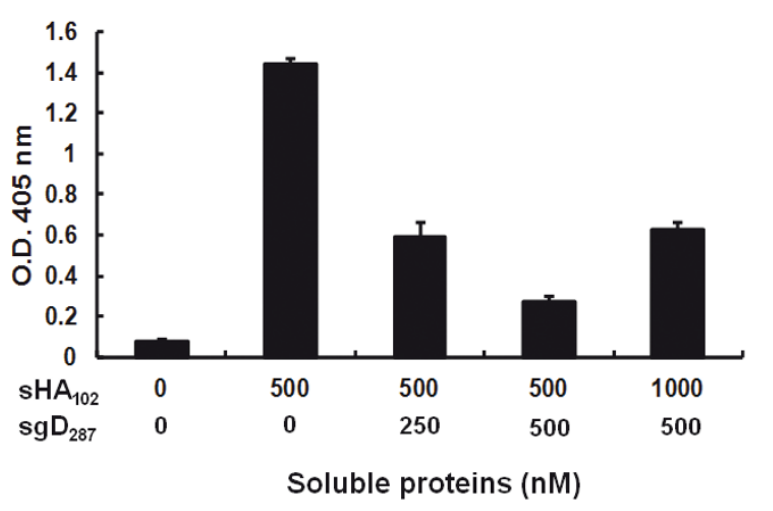

Figure 3 Specificity of $\mathbf{s} \mathbf{H A}_{102}$-mediated entry. (A) Comparison of $\mathrm{sHA} \mathrm{A}_{102}$-mediated $\mathrm{CHO}-\mathrm{K} 1$ infection by KOS/tk12 and a mutant-gD derivative impaired for HVEM binding, KOS-Rid1/tk12, at MOls of 3. (B) Inhibition of $\mathrm{SHA}_{102}$-mediated infection by soluble gD. sHA 102 and $5 g D_{287}$ at the indicated concentrations were incubated with $\mathrm{KOS} / \mathrm{tk} 12$ virus at $4^{\circ} \mathrm{C}$ prior to the addition of $\mathrm{CHO}-\mathrm{K} 1$ cells $(\mathrm{MOI}=3)$ and incubation at $37^{\circ} \mathrm{C}$. Infection was determined by ONPG assay. Values are averages of triplicate determinations. 
A

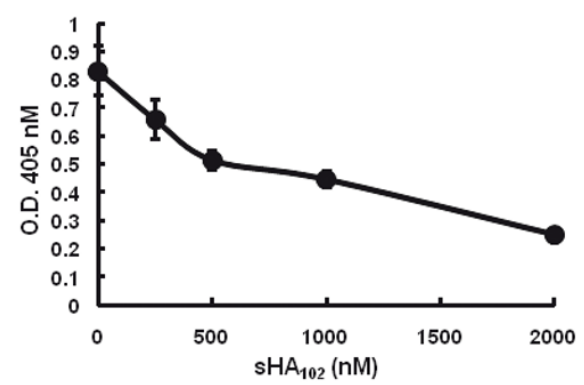

B

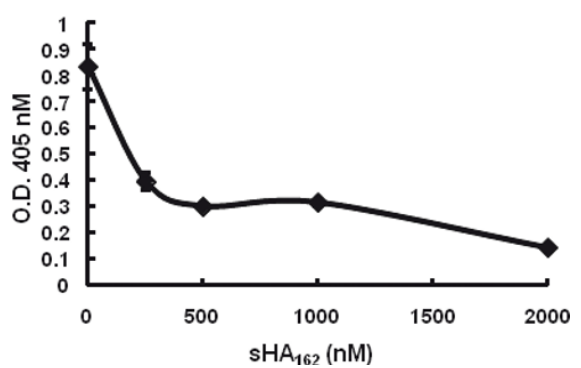

Figure 4 Inhibition of KOS/tk12 infection of HVEM-expressing CHO cells by soluble HVEM proteins. Increasing amounts of sHA $102(A)$ or $\mathrm{SHA}_{162}$ (B) were preincubated with the virus for $1 \mathrm{~h}$ at $4^{\circ} \mathrm{C}$ prior to infection of CHO-HVEM-12 cells $(\mathrm{MOI}=1)$ for $1 \mathrm{~h}$ at $37^{\circ} \mathrm{C}$. The cells were washed and infection was measured $7 \mathrm{~h}$ later by ONPG assay. Values are averages of triplicate determinations.

Pathway of $\mathrm{sHA}_{102}$-mediated HSV entry into $\mathrm{CHO}-\mathrm{K} 1$ cells Previous reports have shown that HSV enters into $\mathrm{CHO}$ cells expressing human nectin-1 or HVEM via a low pH-dependent endocytic pathway [27]. To examine whether the same entry pathway is used in $\mathrm{sHA}_{102^{-}}$ induced HSV-1 infection of CHO-K1 cells, we treated the cells with hypertonic medium or lysosomotropic agents. Medium containing $0.3 \mathrm{M}$ sucrose reduced $\mathrm{sHA}_{102}$-mediated KOS/tk12 infection approximately 5fold (Figure 6B), similar to results reported for HSV infection of HVEM-expressing $\mathrm{CHO}$ cells (Figure 6A) [27], indicating an important role for active endocytosis in entry mediated by $\mathrm{sHA}_{102}$. To determine whether endosomal acidification was required for infection, $\mathrm{CHO}-\mathrm{K} 1$ cells were pre-treated with increasing concentrations of $\mathrm{NH}_{4} \mathrm{Cl}$ or monensin, and incubated with $\mathrm{KOS} / \mathrm{tk} 12$ and $\mathrm{sHA}_{102}$ in the continued presence of these agents. The results showed no inhibition of

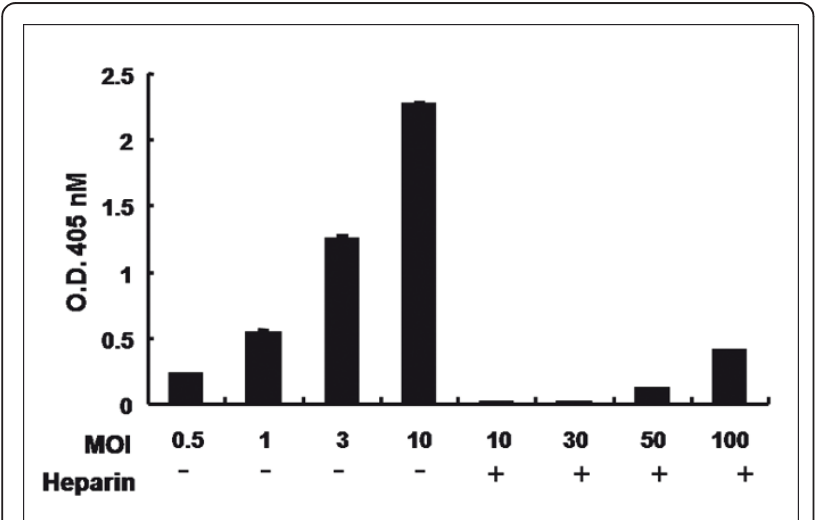

Figure 5 Heparin inhibition of $\mathrm{sHA}_{102}$-mediated KOS/tk12 entry. Virus and heparin $(25 \mu \mathrm{g} / \mathrm{ml})$ were pre incubated for 30 min at $4^{\circ} \mathrm{C}, \mathrm{CHO}-\mathrm{K} 1$ cells were added, and the incubation was continued for another 30 min prior to the addition of $\mathrm{sHA}_{102}(500 \mathrm{nM})$, infection as in previous figures, and ONPG assay. Values are averages of triplicate determinations.
$\mathrm{sHA}_{102}$-mediated infection while infection of $\mathrm{CHO}$ HVEM cells was sensitive to these agents (Figure 6C, D). Thus, unlike HSV infection of HVEM-expressing $\mathrm{CHO}$ cells, $\mathrm{sHA}_{102}$-mediated $\mathrm{CHO}-\mathrm{K} 1$ infection appears to take place by a low $\mathrm{pH}$-independent endocytic mechanism.

\section{Discussion}

In this study, we demonstrate that a soluble gD receptor consisting of the N-terminal 102 amino acids of HVEM is an efficient mediator of HSV-1 infection of receptornegative, $\mathrm{HSV}$-resistant $\mathrm{CHO}-\mathrm{K} 1$ cells. In contrast, sHA $_{162}$, comprising the complete HVEM ectodomain, did not enable viral entry although both $\mathrm{sHA}_{102}$ and $\mathrm{sHA}_{162}$ blocked virus infection of receptor-bearing $\mathrm{CHO}$ cells. We suggest that $\mathrm{sHA}_{162}$ binds to viral gD but prevents the folding of gD into an active conformation that can trigger the fusion process. Using inhibitors of receptor- and $\mathrm{pH}$-dependent endocytosis, we obtained evidence that $\mathrm{sHA}_{102}$-mediated infection of $\mathrm{CHO}-\mathrm{K} 1$ cells occurs by $\mathrm{pH}$-independent endocytosis, unlike the low $\mathrm{pH}$-dependent endocytic mechanism responsible for infection of CHO-HVEM cells [27].

Previous studies have reported inhibition of HSV infection of CHO-HVEM cells by the soluble ectodomain of HVEM, alone [HVEM (200 t)] or as a fusion with the Fc region of rabbit immunoglobulin G (IgG) heavy chain $[6,28]$. In a later study, Whitbeck and colleagues also reported the ability of HVEM (200 t) to promote HSV entry into receptor-deficient $\mathrm{CHO}-\mathrm{K} 1$ cells [31]. Although our sHA ${ }_{162}$ had essentially the same primary sequence as HVEM (200 t), we did not observe an entrypromoting effect of $\mathrm{sHA}_{162}$ on $\mathrm{CHO}-\mathrm{K} 1$ cells. A potentially significant difference with our study is that Whitbeck et al. [31] used a low speed centrifugation technique referred to as spinoculation to augment $\operatorname{HVEM}(200 \mathrm{t})$ mediated virus infection. Spinoculation has been used with HSV and other enveloped viruses to bring virion 


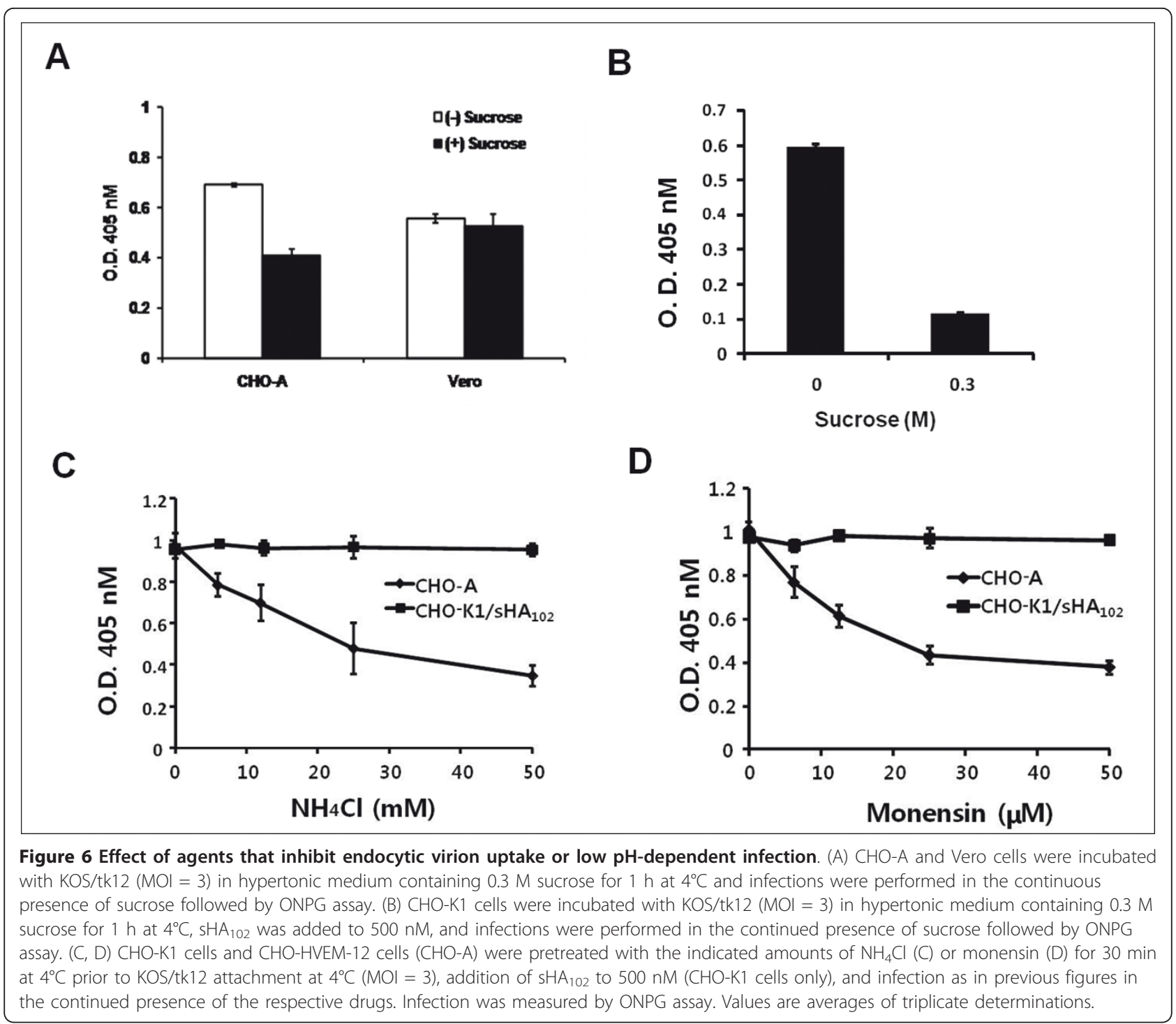

and cell membranes closely together [21,32-34], for example to bypass receptor-dependent virus attachment in studies demonstrating soluble receptor-mediated infection by avian sarcoma and leukosis viruses $[35,36]$. Since HSV attachment to cells is mediated mainly by viral envelope proteins other than $\mathrm{gD}$, we performed our experiments without spinoculation while showing that heparin-sensitive virus attachment was essential under these conditions. We observed highly efficient $\mathrm{sHA}_{102}{ }^{-}$ mediated infection ( $>80 \%$ infection at an MOI of 3 ), but entry mediated by the complete soluble ectodomain was essentially undetectable, suggesting that spinoculation in the study by Whitbeck et al. [31] had allowed the detection of HVEM (200 t) activity by concentrating the virus at the cell surface to raise the sensitivity of the assay. Nonetheless, the Whitbeck study reported a maximum HVEM (200 t)-mediated increase in infection of CHO-
K1 cells of 15.5-fold [5 $\mu$ M HVEM (200 t); MOI = 2], substantially less than the increases we observed at lower $\mathrm{sHA}_{102}$ concentrations (Figure 2). Thus, while $\mathrm{sHA}_{162} /$ HVEM (200 t) may not be inactive in infection of receptor-deficient cells, $\mathrm{sHA}_{102}$ is clearly more effective.

The similar inhibition of CHO-HVEM infection by $\mathrm{sHA}_{102}$ and $\mathrm{sHA}_{162}$ indicated that the difference in entrymediating activity between these two proteins is not due to differences in $\mathrm{gD}$ binding, suggesting that the extra sequences in $\mathrm{sHA}_{162} / \mathrm{HVEM}(200 \mathrm{t})$ compared to $\mathrm{sHA}_{102}$ negatively affect the efficiency of gD activation. The previously reported crystal structure of the gD ectodomain complexed with the HVEM ectodomain has shown that the $\mathrm{N}$-terminal region of gD undergoes a conformational change during HVEM binding [8]. It is conceivable that $\mathrm{sHA}_{102}$ either induces a more global change in the $\mathrm{gD}$ conformation or that the C-terminal portion of $\mathrm{sHA}_{162} /$ 
$\operatorname{HVEM}(200 t)$ interferes with the efficient receptor-dependent unmasking of the gD effector/pro-fusion domain proposed by Krummenacher et al. [12] and Fusco et al. [10].

In the absence of $\mathrm{gD}$ receptors, HSV is internalized by $\mathrm{CHO}$ cells but fails to enter the cytoplasm and is degraded in lysosomes [37]. The presence of gD receptors allows $\mathrm{pH}$-dependent viral capsid escape from endosomes and release into the cytosol [37]. Whitbeck et al. [31] have described evidence that HVEM (200 t) "primes" gD for activation of the membrane fusion machinery, but that a mildly acidic $\mathrm{pH}$ is required in $\mathrm{CHO}$ cells as a second signal for fusion initiation. Surprisingly, our results using $\mathrm{NH}_{4} \mathrm{Cl}$ or monensin to neutralize the endosomal $\mathrm{pH}$ did not show a reduction in $\mathrm{SHA}_{102}$-mediated infection although virus uptake by endocytosis was indicated by reduced infection in media containing $0.3 \mathrm{M}$ sucrose. Thus it appears that the second signal is not required for $\mathrm{sHA}_{102}$ activation of gD. At the opposite end, it appears that endosome acidification as the second signal is not sufficient for efficient activation of gD by $\mathrm{sHA}_{162} / \mathrm{HVEM}$ $(200 \mathrm{t})$. Thus our results suggest that both situations differ from normal virus entry via full-length HVEM. It is of interest that several examples have been reported of cellsurface HVEM failing to serve as a functional HSV entry receptor [38-40], raising the possibility that these cells lack a mechanism to counteract interference by CRPs 3 and 4 with gD activation by full-length HVEM. Our study suggests that $\mathrm{sHA}_{102}$ may be an efficient tool to enable HSV vector-mediated delivery of therapeutic genes to receptordeficient cells.

\section{Conclusions}

Here we have demonstrated a soluble gD receptor, containing N-terminal 102 amino acids of HVEM, for efficient HSV infection into HSV receptor-negative, HSVresistant $\mathrm{CHO}-\mathrm{K} 1$ cells. This study is consistent with two other soluble form of $\mathrm{gD}$ receptors, $\mathrm{sNec}_{123}$ and soluble 3-OS HS. We can improve the usage of $\mathrm{sHA}_{102}$ by fusing it with ligands or receptors of disease related antigens as a promising molecule for retargeting of natural tropism of HSV-1. This retargeting strategy can be combined to create specific recognition by genetic modifications of the virion envelope for incorporation of targeting moiety.

\section{Methods}

\section{Cells and viruses}

African green monkey kidney (Vero) cells were obtained from American Type Culture Collection (ATCC, Rockville, MD) and maintained in Dulbecco's modification of Eagle minimal medium (DMEM) supplemented with 10\% fetal bovine serum (FBS). Chinese hamster ovary cells (CHO-K1, ATCC) were maintained in Ham's F-12 K medium with $10 \% \mathrm{FBS}, 100 \mathrm{U} / \mathrm{ml}$ penicillin, and $100 \mathrm{ug} / \mathrm{ml}$ streptomycin (Invitrogen, Carlsbad, CA). CHO-HVEM-12 cells (Montgomery et al., 1996) are CHO-K1 derivatives constitutively expressing full-length human HVEM and were kindly provided by Patricia G. Spear (Northwestern University, IL, USA). Both cell lines were grown in Ham's F-12 K medium supplemented with 10\% FBS and $400 \mu \mathrm{g} /$ ml G418 (Invitrogen).

Wild-type and mutant gD $\beta$-galactosidase reporter viruses KOS/tk12 and KOS-Rid1/tk12 [29] were kindly provided by Patricia G. Spear and were propagated and titered on Vero cells.

\section{Soluble protein expression constructs}

Sequences encoding $\mathrm{sHA}_{102}$ and $\mathrm{sHA}_{162}$ were amplified by PCR on HVEM plasmid pBEC14 ([6]; a kind gift from Patricia Spear) using the following primers: $\mathrm{sHA}_{102} /$ sHA $_{162}$ sense primer, 5'-CCC AAG CTT GCC ACC ATG GAG CCT CCT GGA GAC TGG GGG CC-3'; sHA $_{102}$ anti-sense primer, 5'-CCC CTC GAG CTA ATG GTG ATG GTG ATG GTG AGC GCG GCA CGC GGC GCA3'; sHA 162 anti-sense primer, 5'-CCC CTC GAG CTA GTG GTG GTG GTG GTG GTG GGA GCT GCT GGT CCC AGC-3'. Primers were designed to provide a Kozak translational initiation sequence at the start of the open reading frame $(\mathrm{ORF})$ and six histidine residues followed by a TAG stop codon at the end. Underlined sequences indicate recognition sites for the restriction enzymes Hind III and Xho I. Following digestion with Hind III plus Xho I, each PCR product was cloned into pcDNA3.1 (+) (Invitrogen), yielding mammalian expression constructs $\mathrm{pHA}_{102}$ and $\mathrm{pHA}_{162}$.

Expression plasmids for $\mathrm{sNec}_{123}$ and $\mathrm{sgD}_{287}$ were as previously described [26].

\section{Production and purification of His fusion proteins}

Soluble proteins were expressed in $293 \mathrm{~T}$ cells and purified using the Probond ${ }^{\mathrm{TM}}$ resin purification system (Invitrogen) according to the manufacturer's protocol. Briefly, DNA transfections were performed with LipofectAmine Plus reagent (Invitrogen) and the cells were then cultured in serum-free media. Culture supernatants were harvested at $72 \mathrm{~h}$ post-transfection, mixed with Probond resin, and incubated for $1 \mathrm{hr}$ at $4^{\circ} \mathrm{C}$. The resin was washed and bound proteins were eluted.

\section{SDS-PAGE and Western blotting}

Purified soluble proteins were electrophoresed on a $12 \%$ polyacrylamide-sodium dodecyl sulfate (SDS) gel and blotted onto Protran nitrocellulose membrane (Whatman $\mathrm{GmbH}$, Dassel, Germany). The membrane was blocked with a solution of $3 \%$ skim milk in PBS/0.1\% Tween-20, and incubated for $1 \mathrm{~h}$ at room temperature with anti-His antibody (Santa Cruz Biotechnology, Santa Cruz, CA) 
diluted in blocking buffer. The membrane was washed three times and treated with horseradish peroxide-conjugated goat anti-mouse IgG (Sigma, St. Louis, MO) for $1 \mathrm{~h}$ at room temperature. Peroxidase activity was detected using an ECL kit (Amersham Pharmacia Biotech, Piscataway, NJ).

\section{HSV entry assay}

CHO-K1 cells in suspension $\left(6 \times 10^{4}\right.$ cells/well $)$ were preincubated with $\mathrm{KOS} / \mathrm{tk} 12$ virus in PBS in a total volume of $40 \mu \mathrm{l}$ for $1 \mathrm{~h}$ at $4^{\circ} \mathrm{C}$ on a rocking device. Increasing concentrations of soluble proteins $(0-1,000 \mathrm{nM})$ were added to the virus/cell mixture and incubated for $1 \mathrm{~h}$ at $37^{\circ} \mathrm{C}$. The cells were collected by centrifugation, washed twice with PBS, resuspended in $40 \mu \mathrm{l}$ of Ham's F-12 K medium, and plated in a single well of a 96 well plate. After continued incubation at $37^{\circ} \mathrm{C}$ for $7 \mathrm{~h}$, virus entry was detected by staining with $\mathrm{X}$-gal (5-bromo-4-chloro-3-indolyl- $\beta$-Dgalactopyranoside) or by colorimetric assay (ONPG, $o$-nitrophenyl- $\beta$-D-galactopyranoside), as previously described [41]. Briefly, infected cell monolayers were fixed with $0.2 \%$ glutaldehyde (Sigma) for $15 \mathrm{~min}$ at room temperature (RT), washed with PBS, and incubated with $0.2 \mathrm{mg} / \mathrm{ml} \mathrm{X}$-gal (Sigma);\% infection was determined by staining of sequential 10 -fold dilutions of infected cells. For the colorimetric assay, infected monolayers were washed with PBS and lysed in $150 \mu \mathrm{l}$ of $1 \% \mathrm{NP}-40,1 \mathrm{mM}$ $\mathrm{MgCl}_{2}, 50 \mathrm{mM} \beta$-mercaptoethanol, and $4 \mathrm{mg} / \mathrm{ml} \mathrm{ONPG}$ (Sigma). Lysates were incubated at $37^{\circ} \mathrm{C}$ until a yellow color developed, and absorbance was measured at $405 \mathrm{nM}$.

\section{Infection inhibition by soluble receptors}

Different concentrations of soluble receptors $(0-2,000$ $\mathrm{nM}$ ) were preincubated with $6 \times 10^{4} \mathrm{pfu}$ of KOS/tk12 in a total volume of $40 \mu \mathrm{l}$ for $1 \mathrm{~h}$ at $4^{\circ} \mathrm{C}$. CHO-HVEM-12 cells $\left(6 \times 10^{4}\right.$ cells/well $)$ were added and the mixture was incubated for $1 \mathrm{~h}$ at $37^{\circ} \mathrm{C}$. The cells were then collected, washed twice with PBS, resuspended in $40 \mu \mathrm{l}$ of Ham's F-12 K medium, and incubated for $7 \mathrm{~h}$ at $37^{\circ} \mathrm{C}$. Infection was measured by colorimetric ONPG assay, as described above.

\section{Infection inhibition by $\mathrm{sgD}_{287}$}

Experiments to determine the sensitivity of $\mathrm{sHA}_{102}$ mediated infection to competition for $\mathrm{sHA}_{102}$ binding with soluble gD were performed essentially as described previously for $\mathrm{sNec}_{123}$ (Kwon et al., 2006). Briefly, various amounts of $\mathrm{sHA}_{102}$ and $\mathrm{sgD}_{287}$ were incubated with $\mathrm{KOS} /$ tk12 in PBS for $1 \mathrm{~h}$ at $4^{\circ} \mathrm{C}$ on rocking device. A total of $5 \times$ $10^{5} \mathrm{CHO}-\mathrm{K} 1$ cells $(\mathrm{MOI}=3)$ were added and the mixture was incubated for $1 \mathrm{~h}$ at $37^{\circ} \mathrm{C}$. The cells were collected, washed, plated with complete medium, and incubated for another $7 \mathrm{~h}$. Infection was measured by ONPG assay.

\section{Heparin inhibition}

Increasing amounts of $\mathrm{KOS} / \mathrm{tk} 12$ were preincubated with $25 \mu \mathrm{l} / \mathrm{ml}$ heparin for $30 \mathrm{~min}$ at $4^{\circ} \mathrm{C}$, CHO-K1 cells were added, and the incubation was continued for another 30 min. $\mathrm{sHA}_{102}$ to a final concentration of 500 $\mathrm{nM}$ was then added and the mixture was incubated for $1 \mathrm{~h}$ at $37^{\circ} \mathrm{C}$. The cells were washed, plated, incubated with complete medium for $7 \mathrm{~h}$ at $37^{\circ} \mathrm{C}$, and infection was determined by ONPG assay.

\section{Endocytosis inhibition assays}

$\mathrm{KOS} / \mathrm{tk} 12(\mathrm{MOI}=3)$ was preincubated with $\mathrm{CHO}-\mathrm{K} 1$ cells for $30 \mathrm{~min}$ at $4^{\circ} \mathrm{C}$ in the presence of $0.3 \mathrm{M}$ sucrose, $\mathrm{sHA}_{102}$ (500 $\mathrm{nM}$ final concentration) was added, and the mixture was incubated for $1 \mathrm{~h}$ at $37^{\circ} \mathrm{C}$. Alternatively, $\mathrm{CHO}-\mathrm{K} 1$ cells were incubated with different concentrations of ammonium chloride $\left(\mathrm{NH}_{4} \mathrm{Cl}\right)$ or monensin (Sigma) for $30 \mathrm{~min}$ at $4^{\circ} \mathrm{C}$, virus was added and the incubation continued for another $30 \mathrm{~min}$ at $4^{\circ} \mathrm{C}$, and $\mathrm{sHA}_{102}$ was added with incubation for $1 \mathrm{~h}$ at $37^{\circ} \mathrm{C}$. In each situation, the cells were washed, plated, and incubated for $7 \mathrm{~h}$ at $37^{\circ} \mathrm{C}$ in complete medium containing the respective inhibitory agents. Virus entry was measured by ONPG assay.

\section{Statistical analysis}

All results were performed in triplicate and the values are expressed as means \pm SD. P values were calculated by using Student's $t$ test, and statistical significance was defined as $P \leq 0.05$.

\section{Abbreviations}

BTLA: B- and T-lymphocyte attenuator; CRPs: Cysteine-rich pseudo repeats; FBS: Fetal bovine serum; gC: Glycoproteins C; gD: Glycoprotein D; HVEM or HveA: Herpes virus entry mediator; HSV-1: Herpes simplex virus type 1; Lt-a: Lymphotoxin alpha; ONPG: o-nitrophenyl- $\beta$-D-galactopyranoside; ORF: Open reading frame; PILRa: Paired immunoglobulin-like type-2 receptor; Tk: Thymidine kinase; TNFR: Tumor necrosis factor receptor; X-gal: 5-bromo-4chloro-3-indolyl- $\beta$-D-galactopyranoside; 3-OS HS: 3-O-sulfated heparan sulfate.

\section{Acknowledgements}

This work was supported by grants National Research Foundation (NFR) (grant code: 20110002169) and National Nuclear R\&D Program of the Ministry of Education, Science, and Technology (MEST) of the Republic of Korea.

\section{Author details}

${ }^{1}$ Division of Radiation Oncology, Korea Institute of Radiological and Medical Sciences, 215-4, Gongneung-Dong, Nowon-Ku, Seoul 139-706, South Korea. ${ }^{2}$ School of Life Sciences and Biotechnology, Korea University, Seoul, South Korea.

\section{Authors' contributions}

$\mathrm{HB}$ and HK designed the research; HB and YN performed research; JK analyzed data; $\mathrm{HB}$ and $\mathrm{HK}$ contributed to drafting the manuscript. All authors read and approved the final manuscript.

\section{Competing interests}

The authors declare that they have no competing interests. 
Received: 17 August 2011 Accepted: 13 January 2012

Published: 13 January 2012

\section{References}

1. Herold BC, Visalli RJ, Susmarski N, Brandt CR, Spear PG: Glycoprotein Cindependent binding of herpes simplex virus to cells requires cell surface heparan sulphate and glycoprotein B. J Gen Virol 1994, 75:1211-1222.

2. Laquerre $S$, Argnani $R$, Anderson DB, Zucchini S, Manservigi R, Glorioso JC: Heparan sulfate proteoglycan binding by herpes simplex virus type 1 glycoprotein B and C, which differ in their contribution to virus attachment, penetration, and cell-to-cell spread. J Virol 1998, 72:6119-6130.

3. Lycke $E$, Johansson M, Svennerholm B, Lindahl U: Binding of herpes simplex virus to cellular heparan sulphate, an initial step in the adsorption process. J Gen Virol 1991, 72:1131-1137.

4. Banfield BW, Leduc Y, Esford L, Schubert K, Tufaro F: Sequential isolation of proteoglycan synthesis mutants by using herpes simplex virus as a selective agent: evidence for a proteoglycan-independent virus entry pathway. J Virol 1995, 69:3290-3298

5. Cocchi F, Menotti L, Mirandola P, Lopez M, Campadelli-Fiume G: The ectodomain of a novel member of the immunoglobulin subfamily related to the poliovirus receptor has the attributes of a bona fide receptor for herpes simplex virus types 1 and 2 in human cells. J Virol 1998, 72:9992-10002

6. Montgomery R, Warner MS, Lum BJ, Spear PG: Herpes simplex virus-1 entry into cells mediated by a novel member of the TNF/NGF receptor family. Cell 1996, 87:427-436.

7. Shukla D, Liu J, Blaiklock P, Shworak NW, Bai X, Esko JD, Cohen GH, Eisenberg RJ, Rosenberg RD, Spear PG: A novel role for 3-O-sulfated heparan sulfate in herpes simplex virus 1 entry. Cell 1999, 99:13-22.

8. Carfi A, Willis SH, Whitbeck JC, Krummenacher C, Cohen GH, Eisenberg RJ, Willey DC: Herpes simplex virus glycoprotein D bound to the human receptor HveA. Mol Cell 2001, 8:169-179.

9. Campadelli-Fiume G, Amasio M, Avitabile E, Cerretani A, Forghieri C Gianni T, Menotti L: The multipartite system that mediates entry of herpes simplex virus into the cell. Rev Med Virol 2007, 17:313-326.

10. Fusco D, Forghieri C, Campadelli-Fiume G: The pro-fusion domain of herpes simplex virus glycoprotein $D(g D)$ interacts with the $\mathrm{gD} M$ terminus and is displaced by soluble forms of viral receptors. Proc Nat Acad Sci USA 2005, 28:9323-9328.

11. Gianni T, Amasio M, Campadelli-Fiume G: Herpes simplex virus gD forms distinct complexes with fusion executors $\mathrm{gB}$ and $\mathrm{gH} / \mathrm{L}$ in part through the C-terminal profusion domain. J Biol Chem 2009, 284:17370-17382.

12. Krummenacher C, Supekar VM, Whitbeck JC, Lazear E, Connolly SA, Eisenberg RJ, Cohen GH, Wiley DC, Carfi A: Structure of unliganded HSV $\mathrm{gD}$ reveals a mechanism for receptor-mediated activation of virus entry. EMBO J 2005, 24:4144-4153.

13. Satoh T, Arii J, Suenaga T, Wang J, Kogure A, Uehori J, Arase N, Shiratori I, Tanaka S, Kawaguchi Y, Spear PG, Lanier LL, Arase H: PILRalpha is a herpes simplex virus-1 entry coreceptor that associates with glycoprotein B. Cell 2008, 132:935-944

14. Arii J, Goto H, Suenaga T, Oyama M, Kozuka-Hata H, Imai T, Minowa A, Akashi H, Arase H, Kawaoka Y, Kawaguchi Y: 2010. Non-muscle myosin IIA is a functional entry receptor for herpes simplex virus-1. Nature 2010, 467:859-862.

15. Geraghty RJ, Krummenacher C, Cohen GH, Eisenberg RJ, Spear PG: Entry of alphaherpesviruses mediated by poliovirus receptor-related protein 1 and poliovirus receptor. Science 1998, 280:1618-1620.

16. Takai Y, Nakanishi H: Nectin and afadin: novel organizers of intercellular junctions. J Cell Sci 2003, 116:17-27.

17. Krummenacher $\mathrm{C}$, Rux AH, Whitbeck JC, Pronce-de-Leon M, Lou H, Baribaud I, Hou W, Zou C, Geraghty RJ, Spear PG, Eisenberg RJ, Cohen GH: The first immunoglobulin-like domain of $\mathrm{HveC}$ is sufficient to bind herpes simplex virus $\mathrm{gD}$ with full affinity, while the third domain is involved in oligomerization of HveC. J Virol 1999, 73:8127-8137.

18. Spear PG: Herpes simplex virus: receptors and ligands for cell entry. Cell Microbiol 2004, 6:401-410.

19. Kwon BS, Tan KB, Ni J, Oh KO, Lee ZH, Kim KK, Kim YJ, Wang S, Gentz R, Yu GL, Harrop J, Lyn SD, Silverman C, Porter TG: A newly identified member of the tumor necrosis factor receptor superfamily with a wide tissue distribution and involvement in lymphocyte activation. J Biol Chem 1997, 272:14272-14276.

20. Cai G, Freeman GJ: The CD160, BTLA, LIGHT/HVEM pathway: a bidirectional switch regulating T-cell activation. Immunol Rev 2009, 229:244-258

21. O'Doherty U, Swiggard WJ, Malim MH: Human immunodeficiency virus type 1 spinoculation enhances infection through virus binding. J virol 2000, 74:10074-10080.

22. Dean HJ, Terhune SS, Shieh MT, Susmarski N, Spear PG: Single amino acid substitutions in $\mathrm{gD}$ of herpes simplex virus 1 confer resistance to $\mathrm{gD}$ mediated interference and cause cell-type-dependent alterations in infectivity. Virology 1994, 199:67-80.

23. Connolly SA, Landsburg DJ, Carfi A, Willey DC, Cohen GH, Eisenberg RJ: Structure-based mutagenesis of herpes simplex virus glycoprotein D defines three critical regions at the gD-HveA/HVEM binding interface. $J$ Virol 2003, 77:8127-8140.

24. Yoon M, Zago A, Shukla D, Spear PG: Mutations in the $\mathbf{N}$ termini of herpes simplex virus type 1 and $2 \mathrm{gDs}$ alter functional interactions with the entry/fusion receptors HVEM, nectin-2, and 3-O-sulfated heparan sulfate but not with nectin-1. J Virol 2003, 77:9221-9231.

25. Whitbeck JC, Connolly SA, Willis SH, Hou W, Krummenacher C, Ponce de Leon M, Lou H, Baribaud I, Eisenberg RJ, Cohen GH: Localization of the gD-binding region of the human herpes simplex virus receptor, HveA. J Virol 2001, 75:171-180.

26. Kwon H, Bai Q, Baek HJ, Felmet K, Burton EA, Goins WF, Cohen JB, Glorioso JC: Soluble $V$ domain of nectin- $1 / \mathrm{HveC}$ enables entry of herpes simplex virus type 1 (HSV-1) into HSV-resistant cells by binding to viral glycoprotein D. J Virol 2006, 80:138-148.

27. Nicola AV, McEvoy AM, Straus SE: Roles for endocytosis and low pH in herpes simplex virus entry into HeLa and Chinese hamster ovary cells. J Virol 2003, 77:5324-5332.

28. Whitbeck JC, Peng C, Lou H, Xu R, Willis SH, Ponce de Leon M, Peng T, Nicola AV, Montgomery RI, Warner MS, Soulika AM, Spruce LA, Moore WT, Lambris JD, Spear PG, Cohen GH, Eisenberg RJ: Glycoprotein D of herpes simplex virus (HSV) binds directly to HVEM, a member of the tumor necrosis factor receptor superfamily and a mediator of HSV entry. J Virol 1997, 71:6083-6093.

29. Warner MS, Geraghty RJ, Martinez WM, Montgomery RI, Whitbeck JC, Xu R, Eisenberg RJ, Cohen GH, Spear PG: A cell surface protein with herpesvirus entry activity (HveB) confers susceptibility to infection by mutants of herpes simplex virus type 1 , herpes simplex virus type 2 , and pseudorabies virus. Virology 1998, 246:179-189.

30. O'Donnell CD, Shukla : The importance of heparan sulfate in herpesvirus infection. Virol Sin 2008, 23:383-393.

31. Whitbeck JC, Zuo Y, Milne RS, Cohen GH, Eisenberg RJ: Stable association of herpes simplex virus with target membranes is triggered by low $\mathrm{pH}$ in the presence of the gD receptor, HVEM. J Virol 2006, 80:3773-3780.

32. Hudson JB: Further studies on the mechanism of centrifugal enhancement of cytomegalovirus infectivity. J Virol Methods 1998, 19:97-108.

33. Scanlan PM, Tiwari V, Bommireddy S, Shukla D: Spinoculation of heparan sulfate deficient cells enhances HSV-1 entry, but does not abolish the need for essential glycoproteins in viral fusion. J Virol Methods 2005, 128:104-112.

34. Tenser RB, Dunstan ME: Mechanisms of herpes simplex virus infectivity enhanced by ultracentrifugal inoculation. Infect Immun 1980, 30:193-197.

35. Damico $R$, Bates $P$ : Soluble receptor-induced retroviral infection of receptor-deficient cells. J Virol 2000, 74:6469-6475.

36. Knauss DJ, Young JA: A fifteen-amino-acid TVB peptide serves as a minimal soluble receptor for subgroup $B$ avian leukosis and sarcoma viruses. J Virol 2002, 76:5404-5410.

37. Nicola AV, Straus SE: Cellular and viral requirements for rapid endocytic entry of herpes simplex virus. J Virol 2004, 78:7508-7517.

38. Manoj S, Jogger CR, Myscofski D, Yoon M, Spear PG: Mutations in herpes simplex virus glycoprotein $D$ that prevent cell entry via nectins and alter cell tropism. Proc Natl Acad Sci USA 2004, 101:12414-12421.

39. Uchida H, Shah WA, Ozuer A, Frampton AR Jr, Goins WF, Grandi P, Cohen JB, Glorioso JC: Generation of herpesvirus entry mediator (HVEM)restricted herpes simplex virus type 1 mutant viruses: resistance of HVEM-expressing cells and identification of mutations that rescue nectin-1 recognition. J Virol 2009, 83:2951-2961. 
40. Tiwari V, Oh MJ, Kovacs M, Shukla SY, Valyl-Nagy T, Shukla D: Role for nectin-1 in herpes simplex virus 1 entry and spread in human retinal pigment epithelial cells. FEBS / 2008, 275:5272-5285.

41. Nakano K, Asano R, Tsumoto K, Kwon H, Goins WF, Kumagai I, Cohen JB, Glorioso JC: Herpes simplex virus targeting to the EGF receptor by a gDspecific soluble bridging molecule. Mol Ther 2005, 11:617-626.

doi:10.1186/1743-422X-9-15

Cite this article as: Baek et al: The soluble amino-terminal region of HVEM mediates efficient herpes simplex virus type 1 infection of gD receptor-negative cells. Virology Journal 2012 9:15.

Submit your next manuscript to BioMed Central and take full advantage of:

- Convenient online submission

- Thorough peer review

- No space constraints or color figure charges

- Immediate publication on acceptance

- Inclusion in PubMed, CAS, Scopus and Google Scholar

- Research which is freely available for redistribution

Submit your manuscript at www.biomedcentral.com/submit 